\title{
Improving energy efficiency of rental housing
}

\author{
Elvira Shagiakhmetova ${ }^{1 *[0000-0002-0475-4374]}$, Danil Burkeev ${ }^{10000-0002-4440-5718]}$, \\ Svetlana Fedorova ${ }^{1[0000-0003-1092-4875]}$, and Diana Shaikhutdinova ${ }^{1 \text { [0000-0002-5543-4477] }}$ \\ ${ }^{1}$ Kazan State University of Architecture and Engineering, 420043 Kazan, Russia
}

\begin{abstract}
Modern cities development is a conscious distribution of priorities. The ecology and resource conservation problems are becoming more and more relevant, and when the city's housing stock is managed, it is necessary to reduce the negative impact on the environment. The aim of the study is to provide an economic feasibility for the construction and the energy-efficient apartment building operation that can serve the needs of current and future generations, and also reduce the carbon footprint through sustainable consumption of electricity and water in domestic buildings. The studying object is an apartment building, in which the introduction of energy-efficient systems is proposed: rainwater harvesting, solar electric plant. During the calculations the questionnaire method, the retrospective indicators of mathematical analysis, the net current value (NPV) method, and the discounted payback period (DPP) method were used. The calculated results showed the effectiveness of the rental housing operation in Kazan (Russia). The payback period will continue for 8.27 years. The practical implementation of the results opens up opportunities for solving the problem of saving natural resources and reducing the carbon footprint of our cities.

Keywords. Construction and operation, energy efficiency, green building, sustainable development, efficiency, NPV, payback period.
\end{abstract}

\section{Introduction}

Nature is the natural habitat of all living beings on the Earth. Our world is rich in natural resources for the life of humanity, however conversations and disputes about climate change and ecological destruction are becoming more and more relevant. There are works devoted to the issues of energy efficiency in the process of construction and buildings and structures operation. This problem is reflected in the works of various foreign authors.

For example, Arvind Chel notes that increasing the buildings environmental friendliness by increasing their energy efficiency has become the paramount worldwide importance [1]. Antti Kosonen, Miguel-Angel Perea-Moreno and Radu Godina say that the of energy consumption reduction in buildings is important, so the major role is the renewable energy sources [2-4]. Hashem Akbaria's article focuses on the necessity to minish the effects of global climate change on the urban environment [5]. Burak Güneralpa argues to reduce the buildings' energy consumption is possible. For that we can upgrade buildings and develop cities more compact [6]. Moreover, the future energy-efficient buildings construction is occurred by the residents need. C. Wilsona, H. Pettifora, and G. Chryssochoidisb found out

*Corresponding author: elvirale@mail.ru 
in their work the opinions of houseowners in the UK concerning the energy-efficient systems during renovation [7].

Jongho Ima writes about energy savings, co-benefits which will help motivate estate property`s owners to invest in energy efficiency, using the US construction industry as an example [8]. Nina Holck Sandberga, who studied the dynamic model of housing development in 11 European countries between 1900 and 2050, found out that $78 \%$ of all residential buildings can benefit from energy efficiency measures by 2050. An increase in energy efficiency will take place during the building (31\%) or reconstruction process $(47 \%)$ [9]. Mark Z. also, using the foreign cities example, shows us that there can be a reduction in annual energy costs by $61.1 \%$ by 2050 and social-energy costs when implementing the strategy for using renewable energy sources in buildings [10].

Authors from the Netherlands: Van Hattum, Sabine Jansen, Saleh Mohammadi and Regina Boke write about alternative energy concepts [11]. Miguel Ángel Pardo examines the issue of effective water and energy resources management on the example of Spain cities [12]. Anna Libey, Marieke Adank, and Evan Thomas also studied the water issue and confirmed the need for a conscious approach to the depleted resources of our planet [13]. At the same time, in the article Francisco J. Díaz says that the reuse of water without analyzing the level of environmental pollution can lead to harmful effects on the soil [14]. And S. Schopfera, for example, in his research studies photovoltaic batteries and speaks about the importance of being able to identify households for which the installation of these systems is economically justified [15].

Kant Kanyarusoke is engaged in the overall green construction methods in frame of sustainable development in Africa [16]. Wan-Yu Shiha is looking for ways to optimize the construction and building system of the Taipei's city by its climatic features [17]. Speaking about the green construction elements, Asterios Papageorgiou shows that the innovation systems' integration into the Swedish power grid does not reduce greenhouse gas emissions, which confirms the need to model the results of green construction within each individual region [18].

T Elkhan Richard Sadik-Zada observes that along with Saudi Arabia, Russia, Iran, Mexico, Canada and Brazil are in the top 20 countries that use fuels with the highest carbon emissions per capita, and many countries, thinking about this, increase the share of renewable energy sources in the energy consumption structure [19]. Consequently, the issues of integrated sustainable development in compliance with the green construction`s requirements are also reflected in the national authors` works [20].

Anna Romanova, Andrey Berval, Danil Burkeev in their article confirm the environmental issues topicality in the modern world, the high human resource consumption`s impact on the environment and prove the importance and relevance of ecological construction [21]. Gulsina Zagidullina, Dilyara Zainullina, Alina Mavlyutova, Elvina Sirazetdinova considers the importance of implementing innovative projects in construction [22].

The review allows us to conclude that the application of the green construction concept is a priority in the frame of sustainable development for the modern cities' development. At the same time, it is necessary to take into account the characteristics of the selected region's climate, because not all systems and resource conservation green technologies will be effective in certain conditions. Thus, the purpose of work is to explain the economic construction and operation efficiency of multi-family building using resource-saving technologies, developed on the basis of potential consumers preferences analysis.

\section{Methods}

1. The questionnaire method for identifying the most significant factors that determine the choice of an apartment building for living. 
2. The retrospective indicators' mathematical analysis: statistical data on the liquid precipitation volume in Kazan (Russia) from April to September from 2011 to 2020.

3. Economic and mathematical analysis of construction and operation efficiency of apartment building in Kazan (Russia) bases on the indicators:

- net present value of the project [23, 24]:

$$
N P V=\sum_{t=2}^{15} \frac{R_{t}+A_{t}+E f_{t}}{(1+d)^{t}}-\sum_{t=2}^{15} \frac{O_{t}}{(1+d)^{t}}-I_{0}
$$

where, $R_{t}$ - rental income; $A_{t}$-other operation income (income from advertising on the facade and in the vestibule of the building from the placement of the vending machine in the vestibule of the building); building $E_{f t}$ - the economic effect of tap water reducing consumption and decreasing electricity costs; $O_{t}$ - operation expenses; $I_{t}$ - initial investment in building construction; $d$-discount rate.

- discounted payback period (PBP).

\section{Results and discussion}

Housing construction, just like humanity, tends to evolve. For many centuries, the people habitat has been transformed in view of the changes in society itself. The life way of different generations representatives was in constant dynamics, society had to adapt to the changing world conditions, to the historical events created by economic development, and therefore, the urban infrastructure had to adapt to the new current needs.

Modern society starts to think more often about its own impact on the environment, as well as more carefully analyzes the items of communal costs. Our city is growing and developing, together with the interests, views and needs of its residents that are also changing. It is also necessary to highlight the problems of ecology, and to show by their own example a reasonable rational using and respect attitude for the natural resources of our region, in order to form a world's correct picture for the younger generations.

To find out what the residents of the city of Kazan mean by the concept of «energyefficient attractive residential building», a survey was conducted among various age population groups using Google form. The questionnaire includes 17 questions. The study involved 1340 respondents who are representatives of different generations the year of birth in 1956 up to $2003.84 \%$ of the respondents are residents of the Republic of Tatarstan, the rest are residents of nearby regions of Russia, which makes it possible to make a qualitative analysis of the preferences of potential consumers of multi-apartment housing stock of the Republic of Tatarstan (Russia).

As a survey result, the Kazan city residents and nearby cities residents helped to form the current preferences of the modern real estate potential market consumers. Thus, an «energyefficient attractive residential building» should:

- have less than 5 floors (44\%);

- have no more than 3 entrances (49,3\%);

- be located in a quiet district with good infrastructure (57\%);

- have alternative electricity sources (wind and solar energy) $(79.8 \%)$;

- have rainwater collection systems for general household needs (for watering green spaces) $(89,4 \%)$;

- have high-quality entrance areas furniture to save the cost of technical maintenance (47.1\%).

Based on consumer preferences, a typical project of a low-rise house was selected (table 1). 
Table 1. The residential building`s characteristic.

\begin{tabular}{|c|l|c|c|}
\hline No. & \multicolumn{1}{|c|}{ Name } & Indicators 'value & Unit measure \\
\hline 1 & Number of floors & 3 & $\mathrm{pc}$. \\
\hline 2 & Number of apartments, total & 12 & $\mathrm{pc}$. \\
\hline 3 & - including: one-room apartments & 10 & $\mathrm{pc}$. \\
\hline 4 & - two-room apartments & 2 & $\mathrm{pc}$. \\
\hline 5 & Building area & 618 & $\mathrm{~m}^{2}$ \\
\hline 6 & Housing system area & 266 & $\mathrm{~m}^{2}$ \\
\hline 7 & Overall dimensions & $20.0 \times 13.3$ & $\mathrm{~m}$. \\
\hline 8 & Floor height & 3 & $\mathrm{~m}$. \\
\hline 9 & The building height & 10.5 & $\mathrm{~m}$. \\
\hline
\end{tabular}

Source: compiled from the materials [25].

The residential building estimated cost was calculated using aggregated cost indicators [26]. The estimated cost is 22217,1611 thousand rubles.

In addition, the costs were calculated for:

- the system installation for collecting roof sedimentary water for next irrigation of green spaces in the adjacent territory;

- the complex solar panels installation to partially provide the house with electricity from a renewable energy source;

- the improved vestibule layout with granite panels for further savings on the entrance space repair due to the durability of the material.

The system`s installation for sedimentary water collecting from the apartment building `s roof is a particularly relevant solution for resource conservation. Early systems installation for roofs sedimentary water collecting can allow the accumulation of fresh water during the rains for watering plants during droughts, as well as reduce the load on the storm collector.

Fig. 1-2 show the stable dynamics of precipitation in Kazan (Russia), expressed in millimeters per square meter. The regions movement which indicates the anomalies possibility in natural conditions from 2011 to 2020 is presented in fig. 1. For example, in August 2011, the precipitation level was only $9 \mathrm{~mm}$, but also this year the maximum level was fixed which was $135 \mathrm{~mm}$ in June.

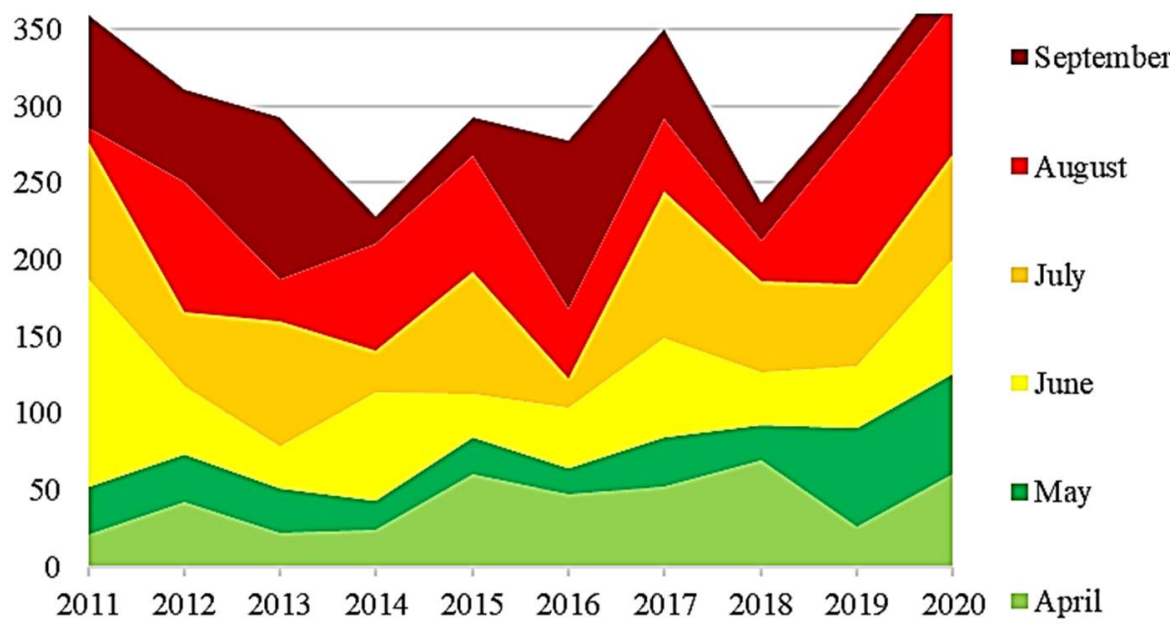

Fig. 1. The liquid precipitation volume from April to September in Kazan (Russia). 


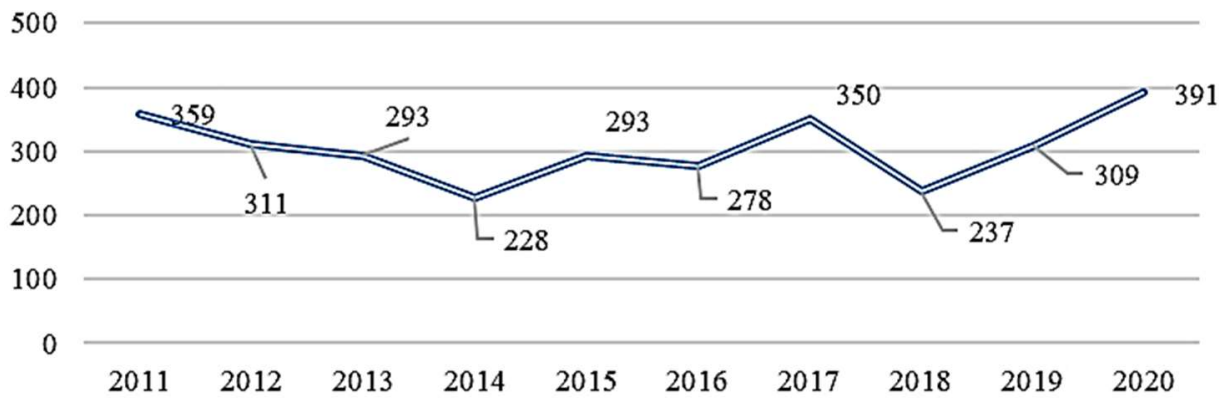

Fig. 2. The average amount liquid precipitation for the warm season, $\mathrm{mm}$.

Due to fig. 2, we can notice that constant amount precipitation of per year annually fixed for the last 10 years in the analysis, which ranges from $237 \mathrm{~mm}$ to $391 \mathrm{~mm}$ in the last 5 years.

Thereby, regardless of possible abnormal weather conditions, the annual precipitation amount in the warm season will be sufficient for its collection.

Table 2. The predicted precipitation's amount accumulated from the roof of the chosen apartment building.

\begin{tabular}{|c|l|c|c|}
\hline No. & \multicolumn{1}{|c|}{ Name } & Value & $\begin{array}{c}\text { Unit } \\
\text { measure }\end{array}$ \\
\hline 1 & The roofing system area & 260 & $\mathrm{~m}^{2}$ \\
\hline 2 & The useful roofing system area (80\%) & 208 & $\mathrm{~m}^{2}$ \\
\hline 3 & The average precipitation amount from April to September & 306.2 & $\mathrm{~mm}$ \\
\hline 4 & $\begin{array}{l}\text { The average precipitation from April to September from the all- } \\
\text { roofing system area }\end{array}$ & 63698.6 & liter \\
\hline 5 & $\begin{array}{l}\text { The weekly watering area of around the house territory due to the } \\
\text { device for collecting water from the roof during precipitation }\end{array}$ & 318.45 & $\mathrm{~m}^{2}$ \\
\hline
\end{tabular}

Source: calculated by the authors.

It was taken into account that the ground surface option for collecting sedimentary water from roofs in urban conditions includes: the tanks purchase, the installation of a base for tanks, the installing and connecting the system costs. The total system cost will be 32102 rubles.

The solar power plant installation is an actual solution that contributes to improving the residential building`s energy-efficiency. The calculations made it possible to determine the rate of basic annual electricity consumption for general household needs in the MCD for houses without an elevator in 5 and less floors $-2 \mathrm{kWh} / \mathrm{m}^{2}$ [27].

The cost of solar panels set, including the system installation, will be 599260 rubles. The cost structure is presented in table 3 .

Table 3. The cost structure of installation solar panels set.

\begin{tabular}{|c|l|c|}
\hline No. & \multicolumn{1}{|c|}{ Name } & Quantity, pc. \\
\hline 1 & Delta BST 250-24P Solar Panel (250W, 24V) & 16 \\
\hline 2 & Solar controller KES DOMINATOR 200/100 (100a) & 1 \\
\hline 3 & AKB Shell 12*210 (210 ah) & 8 \\
\hline 4 & Inverter MAP SIN HYBRID 9 kWt & 1 \\
\hline 5 & Set of cables and connectors & 1 \\
\hline 7 & Mounting kit & 1 \\
\hline
\end{tabular}

Source: Official website of the manufacturer of solar energy storage devices [28].

The granite wall cladding installation of the entrance space, due to the durability and selected material's strength, will save the technical maintenance cost. Calculations on the device were made on the basis of the program «Adept: Construction Management». The 
estimated work cost will be 103185 rubles, the calendar work schedule is presented in table 4 : the duration -7 days.

Table 4. The granite wall cladding of the entrance space work duration.

\begin{tabular}{|c|l|c|}
\hline No. & \multicolumn{1}{|c|}{ Name } & Duration, days \\
\hline 1 & The base for bonding plaster made of metal grid installation & 1 \\
\hline 2 & Bonding plaster surfaces inside the building & 2 \\
\hline 3 & Solid's alignment of the bonding plaster walls & 1 \\
\hline 4 & Wall cladding with slabs & 4 \\
\hline
\end{tabular}

Source: calculation tables from a software program. «Adept: Construction Management» (calculated by the authors).

Thus, the following investment costs were taken into account when performing the calculations: the cost of building a residential house, the land parcel cost, the sedimentary water collection system installation, the solar power plant installation, the walls cladding of the entrance space with granite.

Operating costs are calculated for a period about 14 years and it includes: salaries of the management company employees, utility bills with energy savings. Financial returns during operation are forms by the rental payments, comings from the daily turn-in of apartments from Friday to Sunday during the calendar year.

At the same time, the savings in utility bills as a result of installing a system for collecting sedimentary water from an apartment building's roof and installing a solar panel is 24.46 thousand rubles per year (table 5).

Table 5. The utility bills during operation of residential house.

\begin{tabular}{|c|c|c|c|c|}
\hline \multirow[b]{2}{*}{ No. } & \multirow[b]{2}{*}{ Name } & \multicolumn{2}{|c|}{ Service`s cost, thous. rub. per year } & \multirow{2}{*}{$\begin{array}{c}\text { Saving, } \\
\text { thous. rub. } \\
\text { per year }\end{array}$} \\
\hline & & $\begin{array}{l}\text { excluding resource- } \\
\text { saving systems }\end{array}$ & $\begin{array}{l}\text { including resource- } \\
\text { saving systems }\end{array}$ & \\
\hline 1 & Cold water & 7.56 & 6.19 & 1.36 \\
\hline 2 & Drain system & 14.15 & 12.96 & 1.19 \\
\hline 3 & Electricity supply system & 86.41 & 64.51 & 21.90 \\
\hline 4 & Total & 108.12 & 83.66 & 24.46 \\
\hline
\end{tabular}

Source: calculated by the authors.

Calculated discounted payback period with considering costs and revenues of the project will be 8.27 years, (fig. 3).

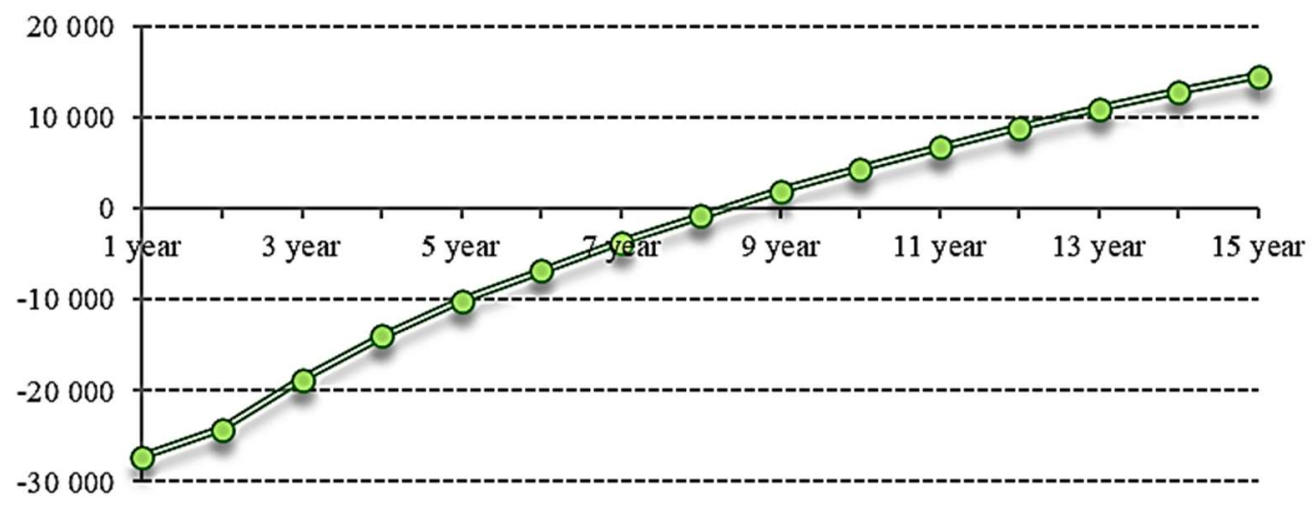

Fig. 3. Discounted payback period calculation tables from a software program «Alt-Invest. Construction» (calculated by the authors). 
The net present value NPV project during 15 years and its implementation (1 construction year and 14 operation's years) is 14649 thousand rubles, which indicates the feasibility of this project in the Kazan (Russia) city`s conditions. Surely, taking care of the environment is not only a gratitude to nature, but also a long-term and economically profitable investment.

\section{Conclusions}

During the study, the economic efficiency of the operation residential building with built-in resourcesaving systems was calculated in accordance with the real estate market potential consumers' preferences. The calculations show that the energy-efficient housing construction is appropriate in the conditions of the researched region. It became economically profitable by reducing costs during the object's operation. At the same time, investments are long-term, since the payback period is 8.27 years. When making management decisions obtained results will help the developing construction projects, as well as in the operation period of a residential apartment building.

\section{References}

1. A. Chel, G. Kaushik. Renewable energy technologies for sustainable development of energy efficient building, J. Alexandria Engineering 57, 655-669 (2018). DOI: 10.1016/j.aej.2017.02.027.

2. A. Kosonen, A. Keskisaari. Zero-energy log house - Future concept for an energy efficient building in the Nordic conditions, J. Energy \& Buildings 228, 110449 (2020). DOI: 10.1016/j.enbuild.2020.110449.

3. M.-A. Perea-Moreno, Q. Hernandez-Escobedo, A.-J. Perea-Moreno. Renewable Energy in Urban Areas: Worldwide Research, J. Trends Energies 11, 577 (2018). DOI: 10.3390/ en11030577.

4. R. Godina, E.M.G. Rodrigues, E. Pouresmaeil, J.C.O. Matias, J.P.S. Catalão. Model Predictive Control Home Energy Management and Optimization Strategy with Demand Response, Appl. Sci. 8, 408 (2018). DOI: 10.3390/app8030408.

5. H. Akbaria, C. Cartalisb, D. Kolokotsac, A. Musciod, A.L. Piselloe, F. Rossie, M. Santamouris, A. Synnefa, N.H. Wongf, M. Zinzig. Local climate change and urban heat island mitigation techniques - the state of the art, J. of civil engineering and management 22 (1), 1-16 (2016). DOI: 10.3846/13923730.2015.1111934.

6. B. Güneralpa, Y. Zhouc, D. Ürge-Vorsatzd, M. Guptad, S. Yue, P.L. Patele, M. Fragkiasf, X. Licgh, K.C. Setog. Global scenarios of urban density and its impacts on building energy use through 2050, J. PNAS 114 (34), 8945-8950 (2017). DOI: 10.1073/pnas.1606035114.

7. C. Wilsona, H. Pettifora, G. Chryssochoidisb. Quantitative modelling of why and how homeowners decide to renovate energy efficiently, J. Applied Energy 212, 1333-1344 (2018). DOI: 10.1016/j.apenergy.2017.11.099.

8. J. Ima, Y. Seob, K. S. Cetinc, J. Singhc. Energy efficiency in U.S. residential rental housing: adoption rates and impact on rent, J. Applied Energy 205, 1021-1033 (2017). DOI: 10.1016/j.apenergy.2017.08.047.

9. N.H. Sandberga, I. Sartorib, O. Heidrichc, R. Dawsonc, E. Dascalakid, S. Dimitrioue, T. Vimmrf, F. Filippidoug, G. Stegnarh, M.S. Zavrlh, H. Bratteba. Dynamic building stock modelling: application to 11 european countries to support the energy efficiency and retrofit ambitions of the EU, J. Energy and Buildings 132, 26-38 (2016). DOI: 10.1016/j.enbuild.2016.05.100.

10. M.Z. Jacobson, A.K. von Krauland, Z.F.M. Burton, S.J. Coughlin, C. Jaeggli, D. Nelli, A.J.H. Nelson, Y. Shu, M. Smith, C. Tan, C. D. Wood, K.D. Wood. Transitioning all 
energy in 74 metropolitan areas, including 30 megacities, to $100 \%$ clean and renewable wind, water, and sunlight (wws), J. Energies 13, 4934 (2020). DOI: 10.3390/en13184934.

11. V. Hattum, T., Snep, R.P.H. Voeten, J.G.W.F., G. Mol. Nature based solutions for urban resilience: a distinction between no-tech, low-tech and high-tech solutions, J. Frontiers in Environmental Science 8, 599060 (2020). DOI: 10.3389/fenvs.2020.599060.

12. M.Á. Pardo, H. Fernández, A. Jodar-Abellan. Converting a water pressurized network in a small town into a solar power water system, J. Energies 13, 4013 (2020). DOI: 10.3390/en13154013.

13. A. Libey, M. Adank, E. Thomas. Who pays for water? Comparing life cycle costs of water services among several low, medium and high-income utilities, J. World Development 136, 105155 (2020). DOI: 10.1016/j.worlddev.2020.105155.

14. F.J. Díaz, J.C. Sanchez-Hernandez, J.S. Notario. Effects of irrigation management on arid soils enzyme activities, J. of Arid Environments 185, 104330 (2021). DOI: 10.1016/j.jaridenv.2020.104330.

15. S. Schopfera, V. Tiefenbecka, T. Staakeb. Economic assessment of photovoltaic battery systems based on household load profiles, J. Applied Energy 223, 229-248 (2018). DOI: 10.1016/j.apenergy.2018.03.185.

16. K. Kanyarusoke. Problems of engineering entrepreneurship in Africa: a design optimization example in solar thermal engineering, J. Engineering Science and Technology 23, 345-356 (2020). DOI: 10.1016/j.jestch.2019.05.002.

17. W.-Y. Shiha, S. Ahmadb, Y.-C. Chenc, T.-P. Lind, L. Mabone. Spatial relationship between land development pattern and intra-urban thermal variations in Taipei, J. Sustainable Cities and Society 62, 102415 (2020). DOI: 10.1016/j.scs.2020.102415.

18. A. Papageorgiou, A. Ashok, T.H. Farzad, C. Sundberg. Climate change impact of integrating a solar microgrid system into the Swedish, electricity grid, J. Applied Energy 268, 114981 (2020). DOI: 10.1016/j.apenergy.2020.114981.

19. E.R. Sadik-Zada, W. Loewenstein. Drivers of $\mathrm{CO}_{2}$-emissions in fossil fuel abundant settings: (pooled) mean group and nonparametric panel, J. Analyses Energies 13, 3956 (2020). DOI: 10.3390/en13153956.

20. M.A. Taimarov, N.F. Timerbaev. Use of wind energy for power supply of construction objects in remote and inaccessible areas, Izvestiya KGASU 2 (52), 98-105 (2020).

21. A.I. Romanova, A.V. Berval, D.O. Burkeev. Efficiency of operational services in the conditions of energy and resource saving, J. Management of economic systems 1, 20 (2019).

22. G.M. Zagidullina, D.R. Zaynullina, A.R. Mavlyutova, E.R. Sirazetdinova. Implementation of innovation projects as a basis for economic development, J. Russian Entrepreneurship 23, 3725-3738 (2017). DOI: 10.18334/rp.18.23.38612.

23. E.I. Shagiakhmetova, M.S. Serdarova. Quantitative analysis of investment projects risks (on the example of engineering branch organization), Discussion 88, 85-92 (2018).

24. E.I. Shagiakhmetova, Yu.V. Medyanik. Assessment of investment in the development of recreational areas of the city of Kazan, J. Manag. Econ. Syst. Sci. Eelectron. J. 12 (130), 86 (2019).

25. Typical project of an apartment building, https://a510.ru/proekty/mnogokvartirnye/ trehetajnyj-mnogokvartirnyj-dom, last accessed 2021.02.04.

26. L.Sh. Gimadieva. Problems of modern standard base of pricing in building, Izvestiya KGASU 2 (14), 327-332 (2010).

27. V.I. Livchak. Regulation of Annual Electricity Consumption in Residential Buildings including for common needs, J. ABOK 6, 46-54 (2015).

28. Official website of the manufacturer of solar energy storage devices, https://econrj.ru/solnechnie-jelektrostancii/solnechnaja-jelektrostancija-28-kvt-ch-vsutki-hybrid-pancir.html, last accessed 2021.02.04. 